\title{
PERAN NILAI PELANGGAN MEMEDIASI PENGARUH CITRA MEREK DAN KUALITAS PELAYANAN TERHADAP KEPUASAN PELANGGAN
}

\author{
Ni Wayan Dian Ratna Anggelina ${ }^{1}$ \\ Ni Made Rastini \\ ${ }^{1,2}$ Fakultas Ekonomi dan Bisnis Universitas Udayana (Unud), Bali, \\ Indonesia \\ E-mail: diananggelina17@gmail.com
}

\begin{abstract}
ABSTRAK
Tujuan penelitian ini adalah untuk menguji peran nilai pelanggan memediasi pengaruh citra merek dan kualitas pelayanan terhadap pepuasan pelanggan PT. Agung Automall Gianyar.Variabel yang diteliti pada penelitian ini adalah variabel nilai pelanggan, citra merek, kualitas pelayanan dan kepuasan pelanggan. Jumlah sampel yang diambil sebanyak 100 responden. Teknik analisis yang digunakan adalah path analysis dengan menggunakan uji sobel. Berdasarkan hasil analisis ditemukan bahwa variabel citra merek berpengaruh positif signifikan terhadap nilai pelanggan, variabel kualitas pelayanan berpengaruh positif signifikan terhadap nilai pelanggan, variabel citra merek berpengaruh terhadap kepuasan pelanggan, variabel kualitas pelayanan berpengaruh positif signifikan terhadap kepuasan pelanggan, variabel nilai pelanggan berpengaruh positif signifikan terhadap kepuasan pelanggan, variabel nilai pelanggan berpengaruh positif signifikan memediasi citra merek terhadap kepuasan pelanggan, variabel nilai pelanggan berpengaruh positif signifikan memediasi kualitas pelayanan terhadap kepuasan pelanggan.
\end{abstract}

Kata Kunci: nilai pelanggan, citra merek, kualitas pelayanan, kepuasan pelanggan

\begin{abstract}
The purpose of this study is to examine the role of customer value mediating the influence of brand image and service quality on customer satisfaction PT. Agung Automall Gianyar. Variables examined in this study are variable customer value, brand image, service quality and customer satisfaction. The number of samples taken was 100 respondents. The analysis technique used is path analysis using the sobel test. Based on the results of the analysis found that the brand image variable has a significant positive effect on customer value, the service quality variable has a significant positive effect on customer value, the brand image variable influences customer satisfaction, the service quality variable has a significant positive effect on customer satisfaction, the customer value variable has a significant positive effect on customer satisfaction, customer value variables have a significant positive effect on mediating brand image on customer satisfaction, customer value variables have a significant positive effect on mediating service quality to customer satisfaction.

Keywords: customer value, brand image, service quality, customer satisfaction
\end{abstract}




\section{PENDAHULUAN}

Seiring dengan pertumbuhan penduduk yang semakin pesat, kebutuhan penduduk pun semakin meningkat, khususnya kebutuhan terhadap transportasi. Transportasi merupakan salah satu kebutuhan masyarakat untuk membantu mobilitas mereka agar sampai di suatu tempat. Dengan banyaknya kebutuhan masyarakat terhadap mobil, semakin berkembang pula pasar mobil di Indonesia. Berkembangnya pasar mobil di Indonesia membuat persaingan menjadi sangat ketat. Hal ini menjadi keuntungan bagi pihak konsumen karena akan semakin banyak pilihan dalam menentukan mobil yang akan digunakan. Penentuan pilihan untuk membeli mobil oleh konsumen dapat dipengaruhi banyak faktor, baik dari harga jual, pelayanan purna jual, kualitas kendaraan, dan sebagainya.

Aryadhe \& Rastini (2016) menyatakan bahwa Bali merupakan destinasi wisata yang berada di kawasan Asia Tenggara. Pariwisata merupakan kegiatan ekonomi yang kompleks, sehingga mampu menggerakkan perekonomian di segala sektor. Tingginya mobilitas masyarakat Bali dan meningkatnya pendapatan serta jumlah wisatawan yang berkunjung ke Bali, menyebabkan kebutuhan akan kendaraan transportasi semakin meningkat. Selain untuk kendaraan pribadi, sebagian besar mobil juga di manfaatkan menjadi kendaraan wisata. Saat ini produsen mobil menjadikan Bali sebagai salah satu pasar yang paling prospektif karena permintaan konsumen yang sangat tinggi. Agar perusahan selalu dilirik oleh kosumen, produsen harus memberikan pelayanan yang berkualitas dan citra merek tetap dijaga.

Kendaraan pribadi (mobil) sebagai sarana transportasi menjadi semakin penting bagi kehidupan manusia saat ini. Aktivitas yang padat dan banyaknya tempat yang harus dituju setiap harinya mendorong manusia untuk memiliki kendaraan yang cepat dan nyaman untuk digunakan. Setiap kendaraan pasti membutuhkan perawatan berkala untuk menjaga performasi, keamanan, dan kenyamanan maksimal. Ketika terjadi kerusakan pada saat digunakan (mogok) banyak pengguna mobil yang tidak bisa memperbaikinya karena pengetahuan tentang kendaraanya yang minim. Hal ini menjadi suatu peluang usaha yang dapat dimanfaatkan untuk membuka jasa layanan service mobil.

Mobil mempunyai risiko penggunaan yang tinggi, sehingga perlu dilakukan perawatan secara periodik untuk menjamin keamanan dan kenyamanan dalam penggunaannya. Kebutuhan konsumen dalam perawatan mobil ini memberikan peluang bagi perusahaan yang bergerak di bidang otomotif yang menyediakan jasa perbaikan yang berupa bengkel untuk memberikan kualitas dan kepuasan agar konsumen menjadi loyal, dan tentunya menjadi harapan perusahaan agar menjadi pelanggan yang melakukan pemakaian ulang jasanya dalam jangka panjang.

Adanya peluang usaha dalam layanan service mobil membuat banyak pengusaha yang tertarik membuka usaha tersebut. Layanan service mobil ini sudah menjamur di berbagai tempat khususnya di Kabupaten Gianyar, terdapat layanan service yang tidak resmi maupun layanan service yang resmi yang ada di Kabupaten Gianyar. Setiap layanan service pasti terdapat fasilitas dan keunikan yang berbeda. Utamanya bagian mekanik yang melayani pelanggan yang membutuhkan service. Adanya persaingan antar pengusaha bengkel yang semakin 
ketat juga mendorong perusahaan kendaraan mobil untuk mendirikan layanan service mobil.

Dewasa ini perhatian terhadap pelanggan semakin besar, bahkan semakin banyak dealer yang menaruh perhatian terhadap layanan service yang harus diberikan. Persaingan yang semakin ketat, dimana semakin banyak dealer yang terlibat dalam pemenuhan kebutuhan dan keinginan service pelanggan menyebabkan setiap dealer harus menempatkan orientasi pada kepuasan pelanggan sebagai tujuan utama. Hal ini tercermin dan semakin banyaknya dealer yang menyertakan komitmennya terhadap kepuasaan pelanggan dalam pernyataan visinya.

Perusahaan juga perlu menciptakan kepuasan pelanggan, sebab ketidakpuasan pelanggan dapat berdampak pada berpindahnya pelanggan pada pesaing. Dalam pikiran seseorang, dengan menggunakan bengkel resmi maka biaya yang dikeluarkan akan terasa mahal. Hal inilah yang harus dihindari, karena dengan melakukan perawatan rutin di bengkel resmi maka kendaraan akan terjamin kenyamanannya serta umur kendaraan akan lebih lama.

Kepuasan pelanggan adalah suatu keadaan dimana keinginan, harapan dan kebutuhan pelanggan dipenuhi (Siswanto \& Widjaja, 2017). Pelanggan adalah orang yang tidak tergantung pada kita, tetapi kita yang tergantung padanya, orang yang membawa kita kepada keinginannya dan orang yang teramat penting yang harus dipuaskan (Gaspersz, 2004). Bowen \& McCain (2015) dan Lee (2013) mengemukakan bahwa kepuasan pelanggan terkait dengan loyalitas dan loyalitas, pada gilirannya, terkait dengan kinerja organisasi layanan. Dengan demikian kelangsungan hidup dari bisnis yang dijalankan ditentukan oleh bagaimana strategi yang digunakan oleh suatu perusahaan dalam rangka memuaskan kebutuhan para palanggan sesuai dengan apa yang diharapkan bahkan melampauinya, karena mempertahankan pelanggan yang sudah ada lebih sulit dibandingkan mencari pelanggan baru yang tentunya akan memakan biaya yang lebih tinggi seperti memasang promosi atau iklan yang lebih sering.

Wardhana (2013) menyatakan bahwa citra merek adalah sebagai persepsi dan preferensi pelanggan terhadap suatu merek, dimana direfleksikan melalui berbagai tipe asosiasi merek yang melekat dalam ingatan pelanggan. Adapun asosiasi tersebut dapat dihasilkan dari pengalaman langsung dengan produk atau jasa, dari informasi yang dikomunikasikan (melalui perusahaan itu sendiri, sumber komersial lainnya, dan mulut-ke-mulut), dan sebagainya. Dalam persepsi konsumen, pada umumnya merek service mobil yang dipilih adalah merek serice mobil yang memberikan citra merek yang baik dan telah melekat dalam ingatan konsumen.

Wardhana (2013) menyatakan bahwa citra merek bengkel mobil resmi akan memberikan pengaruh terhadap pelanggan akan keyakinan kualitas jasa bengkel, apakah handal atau kurang handal. Dengan citra merek yang disandangnya harus memberikan manfaat yang besar dibandingkan segala pengorbanan yang dikeluarkannya, sebagaimana dijelaskan oleh Kotler \& Armstrong (2012:269) bahwa merek akan membantu pembeli dalam berbagai cara, dimana nama merek akan membantu konsumen untuk mengidentifikasi produk/jasa sehingga dapat merasakan manfaatnya, dan merek akan menjelaskan kualitas produk/ jasa kepada pembeli. 
Keberadaan service resmi suatu dealer mobil sangat dinantikan dan diharapkan oleh pelanggan untuk memenuhi kebutuhan akan perawatan dan perbaikan kendaraannya. Salah satu upaya yang perlu dilakukan oleh bengkel dealer mobil yaitu mengelola dan menjaga citra merek service resmi dengan baik sehingga sedemikian rupa akan menghasilkan citra merek bengkel mobil resmi yang positif dalam upaya untuk membangun nilai pelanggan.

Peran kualitas pelayanan juga tidak kalah penting dari peran citra merek karena sama- sama mempengaruhi kepuasan pelanggan. Menurut Pramana \& Rastini (2016) menyatakan bahwa kualitas pelayanan merupakan suatu bentuk penilaian, terhadap tingkat layanan yang diberikan oleh suatu perusahaan. Setiap perusahaan perlu berupaya memahami harapan pelanggan atas produk yang dihasilkan atau jasa/layanan yang diberikan. Perusahaan yang memiliki layanan yang superior akan dapat memaksimalkan performa keuangan perusahaan (Gilbert et al., 2004). Menurut Hardiansyah (2011) bahwa yang harus diperhatikan dalam kualitas jasa pelayanan, yaitu: Bukti fisik (Tangibles), Empati (Emphaty), Keandalan (Reliability), Daya tanggap (Responsiveness), Jaminan (Assurance).

Raza et al. (2015) menunjukkan bahwa kualitas layanan secara positif terkait dengan kepuasan pelanggan dalam konvensional industri perbankan Pakistan. Keyser \& Lariviere (2014) berpendapat bahwa kualitas layanan teknis dan fungsional memiliki dampak positif pada kebahagiaan konsumen. Studi baru-baru ini menggarisbawahi fakta bahwa baik kualitas fungsional dan teknis memiliki efek vital pada kepuasan pelanggan dalam memberikan layanan berkualitas tinggi. Kualitas adalah kesesuaian dengan spesifikasi, meskipun baru-baru ini dianggap memenuhi atau melebihi harapan pelanggan (Ariffin \& Maghzi, 2012). Pelayanan service pada service resmi suatu dealer mobil akan menjadi suatu jaminan terhadap suatu merek mobil tertentu sehingga mobil tersebut diminati oleh pelanggan.

Pelanggan akan memilih service yang handal yang dapat memberikan kepuasan, apakah menggunakan jasa bengkel resmi atau bengkel tidak resmi, dimana akan membandingkan berapa total biaya yang dikeluarkan (monetary cost \& non-monetary cost) dan besarnya total manfaat (benefit) dalam menjadikan kendaraan tersebut tetap prima. Dengan demikian konsumen otomotif di Bali akan semakin kritis dalam menentukan dan memilih suatu kendaraan. Kendaraan yang dipilih adalah kendaraan yang sedikit menghasilkan keluhan pelanggan dan memberikan kepuasan terhadap pelayanan jasa bengkelnya.

Jika citra merek dan kualitas pelayanan buruk maka besar kemungkinan untuk pelanggan berpindah ke bengkel tidak resmi lainnya. Khususnya bagi pelanggan diluar masa garansi kendaraannya cenderung untuk menggunakan bengkel non-resmi dengan berbagai pertimbangannya. Faktor pelayanan purna jual yang handal seperti garansi mesin sampai dengan batas kilometer tertentu, tersedianya jasa pelayanan bengkel, ketersediaan suku cadang, dan lain sebagainya merupakan faktor yang dipertimbangkan oleh konsumen selain faktor eksterior, interior, dan harga yang ditawarkan oleh bengkel resmi.

Faktor selanjutnya yang dapat berperan penting dalam memberikan pengaruh pada kepuasan pelanggan adalah nilai bagi pelanggan. Alasan memilih nilai pelanggan sebagai variabel intervening atau mediasi karena terdapat pengaruh hubungan antara variabel kepuasan pelanggan dengan variabel citra merek dan 
kualitas pelayanan menjadi hubungan yang tidak langsung dan tidak dapat diamati dan diukur. Menurut Yang \& Peterson (2004) nilai pelanggan merupakan evaluasi hasil perbandingan persepsi seseorang terhadap hasil dari pelayanan, kualitas dan manfaat yang diberikan dengan pengorbanan yang dibayarnya. Selain itu, kepuasan pelanggan memiliki pengaruh terbesar pada loyalitas ketika dipertimbangkan bersama dengan nilai pelanggan dan citra merek (Lai et al., 2009).

Dengan ini, perusahaan yang menghasilkan produk atau jasa harus meningkatkan citra merek dan kualitas pelayanan agar pelanggan yang telah membeli produk atau jasa merasa puas. PT. Agung Automall juga mengutamakan kualitas pelayanan dalam memberikan service mobil kepada pelanggan.

Berbagai upaya peningkatan kualitas pelayanan sesuai dengan persepsi dan harapan pelanggan dilakukan oleh PT. Agung Automall Gianyar dalam membentuk citra merek yang positif kepada pelanggan untuk meningkatkan nilai yang dirasakan oleh pelanggan (customer value) serta dalam rangka memberikan kepuasan kepada pelanggan untuk senantiasa menggunakan jasa pelayanan bengkel resmi, seperti dengan memperluas jaringan bengkel resmi yang tersebar hingga pelosok negeri, kemudahan memperoleh suku cadang kendaraan, ketersediaan mekanik yang berpengalaman dan bersertifikasi, dan lain sebagainya.

Hasil penelitian terdahulu yang berkaitan dengan variabel citra merek, kualitas pelayanan, nilai pelanggan, dan kepuasan pelanggan teridentifikasi adanya research gap antara hubungan variabel tersebut. Brand image (citra merek) mempunyai peran yang sangat penting karena membantu pelanggan dalam memilih jasa yang akan memberikan pelayanan jasa yang baik dan memberikan kepuasan tersendiri bagi para pelanggan. Hal tersebut didukung dengan hasil penelitian yang dilakukan oleh (Dewi, 2013). Adapun hasil penelitian menunjukan bahwa citra merek berpengaruh terhadap kepuasan pelanggan, sedangkan hasil penelitian yang berbeda yang dilakukan oleh Sondakh (2014) yang menyatakan bahwa variabel citra merek berpengaruh tidak signifikan terhadap variabel kepuasan nasabah Taplus BNI Cabang Manado. Selain itu terdapat hasil lain yang berbeda dengan penelitian yang dilakukan oleh Dewi (2013) dengan judul penelitian Analisis Pengaruh Kualitas Produk, Citra Merek, Kepercayaan Dan Kepuasan Terhadap Loyalitas Pengguna Produk Advan Di Kota Semarang yang hasil penelitiannya menunjukkan bahwa Citra merek berpengaruh negatif dan signifikan terhadap loyalitas pengguna produk Advan di Kota Semarang, artinya bahwa semakin tinggi citra merek, maka semakin rendah loyalitas.

Menurut Tjiptono (2016) menyatakan Kualitas pelayanan adalah tingkat keunggulan yang diharapkan dan pengendalian atas tingkat keunggulan tersebut untuk memenuhi keinginan pelanggan. Dengan demikian jika sebuah perusahaan memberikan kualitas pelayanan yang terbaik maka kepuasaan pelanggan akan tewujud hal tersebut dikarenakan berhasilnya perusahaan jasa dalam memenuhi keinginan pelanggan melalui kualitas pelayanan yang terbaik. Hal tersebut didukung dengan penelitian yang dilakukan oleh Permana (2016) dengan hasil penelitian menunjukan bahwa Secara parsial, kualitas pelayanan berpengaruh signifikan terhadap kepuasan konsumen Starbucks BIP dengan kontribusi pengaruh yang diberikan sebesar 33,0\%. Sedangkan hasil penelitian berbeda dari penelitian yan dilakukan oleh Kumalasari (2018) yang menunjukkan bahwa variabel kualitas 
produk dan kualitas pelayanan tidak berpengaruh signifikan terhadap kepuasan konsumen Tempe 5.17. Mengingat ketidak konsistenan hasil pengujian tersebut, maka peneliti ingin menguji kembali penelitian sebelumnya dengan melibatkan nilai pelanggan sebagai variabel mediasi untuk mengetahui hasil dari pengaruh citra merek dan kualitas pelayanan terhadap kepuasan pelanggan.

PT. Agung Automall Gianyar adalah bengkel resmi toyota untuk jasa perbaikan dan perawatan. Beberapa jenis fasilitas yang diberikan antara lain: service gratis selama masa garansi yang dimanfaatkan oleh konsumen untuk merawat atau memperbaiki kendaraannya pada bengkel resmi. Setelah masa garansi berlalu konsumen dapat memilih bengkel yang mana selanjutnya akan dikunjungi, apakah masih tetap menggunakan jasa bengkel resmi atau beralih ke bengkel umum (tidak resmi).

Perusahaan Toyota mendirikan jasa layanan service dengan nama PT. Agung Automall Gianyar. PT. Agung Automall tersebut hanya melayani service untuk mobil dengan merek Toyota. Bengkel PT. Agung Automall Gianyar juga menyediakan berbagai macam keperluan atau yang biasa disebut dengan nama spare part khusus untuk mobil yang diproduksi oleh perusahaan Toyota sendiri. Hal tersebut membuat pelanggan yang melakukan perawatan mobilnya di PT. Agung Automall Gianyar dapat terjamin karena semua yang disediakan merek Toyota. Biasanya pelanggan PT. Agung Automall yang menggunakan jasa service tersebut mempunyai buku serviceyang bisa mencatat jangka waktu pelanggan tidak melakukan service sepeda motornya.

PT. Agung Automall Gianyar merupakan salah satu bengkel resmi untuk mobil merek Toyota memiliki lokasi yang strategis di kawasan kota yaitu di Jalan Dharma Giri, Buruan, Blahbatuh, Gianyar. Kondisi tersebut menjadikan PT. Agung Automall Gianyar sebagai bengkel resmi Toyota yang memiliki pemakai jasa atau pelanggan yang cukup tinggi. Jumlah rata-rata pelanggan perhari sampai dengan 20 pelanggan, ini dibuktikan dari data yang diperoleh dari PT. Agung Automall Gianyar selama bulan Desember 2017 hingga Februari 2018.

Alasan dalam pemilihan bengkel resmi mobil Toyota (PT. Agung Automall Gianyar) sebagai objek penelitian adalah karena PT. Agung Automall Gianyar ini merupakan salah satu dari beberapa bengkel mobil resmi yang melayani service dan mampu bertahan meskipun banyak bermunculan bengkel-bengkel mobil baru di kota Gianyar.

Menurut Kotler \& Armstrong (2012:269) bahwa merek akan membantu pembeli dalam berbagai cara, dimana nama merek akan membantu konsumen untuk mengidentifikasi produk atau jasa sehingga dapat merasakan manfaatnya. Apabila citra merek merupakan citra merek yang positif, maka citra merek tersebut akan berdampak pada penilaian pelanggan.

Solechah \& Soliha (2015) mengungkapkan jika citra merek berpengaruh positif signifikan terhadap nilai pelanggan. Selanjutnya menurut Wardhana (2013) menyatakan bahwa citra merek berpengaruh positif signifikan terhadap nilai pelanggan pada penelitiannya yang dilakukan pada pelanggan bengkel resmi kendaraan mpv dibawah 2500 cc di Kota Bandung.

Penelitian yang diungkapkan oleh (Antonio, 2007) menyatakan bahwa pengaruh citra merek positif dan signifikan terhadap nilai pelanggan, hal ini 
menunjukkan sebagian besar pelanggan beranggapan bahwa popularitas nama bengkel menjadikan manfaat jasa bengkel resmi yang sangat besar. Oleh karena itu dapat dirumuskan hipotesis sebagai berikut:

$\mathrm{H}_{1}$ : Variabel citra merek berpengaruh positif dan signifikan terhadap variabel nilai pelanggan.

Andhansari et al. (2012) menyatakan bahwa untuk mencapai nilai pelanggan yang tinggi, maka perusahaan perlu memberikan kualitas pelayanan pelanggan yang lebih baik daripada pesaingnya.

Kanthi et al. (2016) mengungkapkan bahwa kualitas pelayanan berpengaruh positif dan signifikan terhadap nilai pelanggan, diman pelanggan menilai bahwa nilai dan manfaat yang dirasakan sesuai dengan pengorbanan yang telah dikeluarkan sesuai dengan kualitas layanan yang telah diberikan.

Penelitian Razavi et al. (2012) menyatakan bahwa kualitas layanan memiliki pengaruh yang kuat terhadap nilai pelanggan. Bahkan dalam penelitian ini, variabel kualitas layanan memiliki pengaruh paling kuat terhadap nilai pelanggan, dibandingkan variabel- variabel lainnya yaitu kepuasan dan loyalitas.

Penelitian Lee \& Lee (2011), menyatakan bahwa kualitas layanan berpengaruh positif dan signifikan terhadap nilai pelanggan. Ketika instansi atau perusahaan mempertimbangkan, bukan hanya nilai pelanggan dari segi sifat jasa layanan saja, tetapi juga dampak akan layanan tersebut bagi pelanggan serta makna psikologis yang terkait dengan nilai pelanggan yang pada akhirnya meningkatkan kualitas layanan akan menghasilkan manfaat terbesar pada nilai pelanggan. Maka dari itu dapat dirumuskan hipotesis sebagai berikut:

$\mathrm{H}_{2}$ : Variabel kualitas pelayanan berpengaruh positif dan signifikan terhadap variabel nilai pelanggan.

Citra merek merupakan image atau sesuatu yang melekat di benak konsumen. Semakin baik persepsi di benak konsumen terhadap citra merek perusahaan maka kepuasan konsumen juga akan semakin tinggi.

Penelitian yang dilakukan oleh (Herliza \& Saputri, 2016) menunjukkan tanggapan pelanggan terhadap brand image pada Zara dalam kategori "Tinggi", artinya image yang dibentuk oleh Zara sesuai dengan kepuasan pelanggan yang dimana citra merek berpengaruh positif terhadap kepuasan pelanggan. Selanjutnya penelitian yang dilakukan oleh Kunaifi (2015) menyatakan bahwa citra merek sangat berpengaruh positif signifikan terhadap kepuasan pelanggan produk eiger di kota Surakarta.

Pusparani \& Rastini (2014) menyatakan citra merek berpengaruh positif signifikan terhadap kepuasan pelanggan apabila perusahaan senantiasa membentuk citra positif merek, menciptakan ciri khas dari merek, dan lebih mengenalkan merek produk ke masyarakat luas, dampaknya adalah, konsumen akan merasa puas karena menggunakan merek produk yang dikenal luas oleh masyarakat. Maka hipotesis yang diajukan adalah sebagai berikut:

$\mathrm{H}_{3}$ : Variabel citra merek berpengaruh positif dan signifikan terhadap variabel kepuasan pelanggan. 
Hidayat (2009) menyatakan bahwa hubungan kualitas layanan dan kepuasan pelanggan tidak lepas dari pembicaraan kreativitas layanan instansi atau perusahaan. Instansi atau perusahaan harus mampu mengidentifikasi siapa yang menjadi pelanggannya untuk mewujudkan suatu layanan berkualitas yang bermuara pada kepuasan pelanggan, sehingga mampu memahami tingkat persepsi dan harapan pelanggan atas kualitas layanan.

Penelitian Lee \& Lee (2011) dan Patawayati et al. (2013) menyatakan bahwa kualitas pelayanan berpengaruh positif dan signifikan terhadap kepuasan pelanggan, dan menyatakan bahwa kualitas layanan mempengaruhi kepuasan pelanggan. Kualitas layanan dan kepuasan dianggap sebagai dua sisi dari koin yang sama. Kepuasan merupakan perbandingan kinerja layanan dan harapan pelanggan. Penyedia jasa harus merencanakan dan melaksanakan strategi layanan bagi pelanggan yang berorientasi untuk medis agar dengan strategi tersebut akan meningkatkan kepuasan. Maka hipotesis yang diajukan adalah sebagai berikut:

$\mathrm{H}_{4}$ : Variabel kualitas pelayanan berpengaruh positif dan signifikan terhadap variabel kepuasan pelanggan.

Seorang pelanggan yang puas adalah pelanggan yang merasa mendapatkan value dari produsen atau penyedia jasa. Value ini bisa berasal dari produk, pelayanan, sistem atau sesuatu yang bersifat emosional. Value bagi pelanggan ini dapat diciptakan melalui atributatribut pemasaran perusahaan yang dapat menjadi unsur-unsur stimulasi bagi perusahaan untuk mempengaruhi konsumen dalam pembelian. Jika pembelian yang dilakukan mampu memenuhi kebutuhan dan keinginannya atau mampu memberikan kepuasan, terjadi pembelian ulang pada masa depan (Palilati, 2007).

Selain itu menurut Iskandar \& Dendy (2013) berdasarkan hasil uji dapat disimpulkan nilai pelanggan yang terdiri dari emotional value, social value, performance value, dan price value secara serempak dan simultan berpengaruh positif signifikan terhadap kepuasan pelanggan. Selanjutnya menurut Febrianto (2010) nilai pelanggan mempunyai pengaruh tidak langsung terhadap kepuasan pelanggan dan berpengaruh positif signifikan. Maka dari itu dapat dirumuskan hipotesis sebagai berikut:

$\mathrm{H}_{5}$ : Variabel nilai pelanggan berpengaruh positif dan signifikan terhadap variabel kepuasan pelanggan.

Pramudyo (2012) yang menemukan bahwa citra merek berpengaruh positif dan signifikan terhadap kepuasan konsumen. Dapat disimpulkan bahwa semakin melekat citra merek atau produk tertanam dalam benak pelanggan maka kepuasan yang dirasakan oleh pelanggan akan semakin tinggi.

Penelitian yang diungkapkan oleh Antonio (2007) menyatakan bahwa pengaruh citra merek positif dan signifikan terhadap nilai pelanggan, hal ini menunjukkan sebagian besar pelanggan beranggapan bahwa popularitas nama bengkel menjadikan manfaat jasa bengkel resmi yang sangat besar. Menurut Bestari \& Nurdasila (2017) mengemukakan bahwa sesungguhnya peran dari nilai 
pelanggan positif dapat memuaskan pelanggan melalui citra merek. Maka dari itu dapat dirumuskan hipotesis sebagai berikut:

$\mathrm{H}_{6}$ : Citra merek berpengaruh positif dan signifikan terhadap kepuasan pelanggan dengan nilai pelanggan sebagai variabel mediasi.

Persepsi seorang pelanggan terhadap nilai atas kualitas yang ditawarkan relatif lebih tinggi dari pesaing akan mampu memberikan pengaruh terhadap tingkat kepuasan pelanggan (Palilati, 2007). Aryani \& Rosinta (2010) menyatakan kualitas layanan terhadap kepuasan pelanggan yang dimediasi oleh nilai pelanggan pada studi kasus konsumen KFC di Semarang secara positif dan signifikan.

Selanjutnya Woro \& Naili (2013) mengungkapkan bahwa kualitas pelayanan mempunyai pengaruh tidak langsung terrhadap kepuasan pelanggan melalui nilai pelanggan. Hal ini menunjukkan bahwa semakin tinggi kualitas layanan PO Efisiensi yang diberikan kepada pelanggan, maka akan semakin besar pula kepuasan yang dirasakan oleh pelanggan. Maka dari itu dapat dirumuskan hipotesis sebagai berikut:

$\mathrm{H}_{7}$ : Kualitas pelayanan berpengaruh positif dan signifikan terhadap kepuasan pelanggan dengan nilai pelanggan sebagai variabel mediasi.

\section{METODE PENELITIAN}

Penelitian dilakukan di PT. Agung Automall Gianyar yang terletak di Jalan Dharma Giri, Buruan, Blahbatuh, Gianyar, Bali (80851). Peneliti memilih PT. Agung Automall Gianyar untuk diteliti karena PT. Agung Automall Gianyar mengalami perkembangan yang cukup baik di tengah persaingan dunia otomotif saat ini di Kabupaten Gianyar, sehingga peneliti tertarik untuk meneliti tentang kualitas- kualitas yang ditawarkan Agung Automall agar dapat membangun kepuasan pelanggan yang baik serta mampu memberikan manfaat atau value pada masyarakat pengguna mobil merek Toyota di Kabupaten Gianyar.

Populasi dalam penelitian ini adalah pelanggan PT. Agung Automall Gianyar yang aktif berkunjung dan rutin melakukan layanan service mobil di PT. Agung Automall Gianyar.

Ukuran sampel terbaik untuk mengukur multivariate adalah 5-10 observasi setiap indikator yang diestimasi. Responden yang bisa digunakan dalam penelitian ini berjumlah antara 70 sampai dengan 130 responden. Karena keterbatasan dan pertimbangan peneliti maka dalam penelitian ini hanya menggunakan 100 orang responden.

Teknik analisis data dalam penelitian ini menggunakan analisi jalur. Adapun persamaannya adalah sebagai berikut:

Sub-struktural 1

$\mathrm{M}=\beta_{1} \mathrm{X}_{1}+\beta_{2} \mathrm{X}_{2}+\mathrm{e}_{1}$

Sub-struktural 2

$\mathrm{Y}=\beta_{3} \mathrm{X}_{1}+\beta_{4} \mathrm{X}_{2}+\beta_{5} \mathrm{M}+\mathrm{e}_{2}$

Keterangan:

$\mathrm{Y} \quad$ Kepuasan Pelanggan

$\mathrm{X}_{1}=$ Citra Merek 


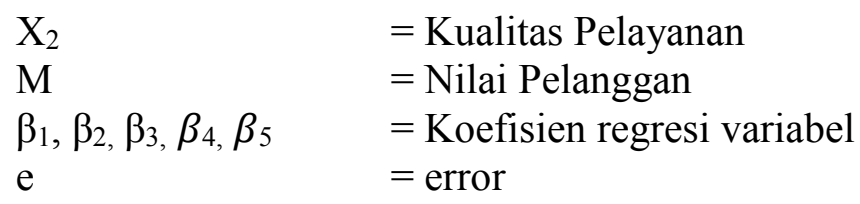

\section{HASIL DAN PEMBAHASAN}

Tabel 1.

Hasil Analisis Jalur Persamaan Regresi 1

\begin{tabular}{|c|c|c|c|c|c|c|}
\hline \multirow{2}{*}{\multicolumn{2}{|c|}{ Model }} & \multicolumn{2}{|c|}{$\begin{array}{l}\text { Unstandardized } \\
\text { Coefficients }\end{array}$} & \multirow{2}{*}{$\begin{array}{c}\text { Standardized } \\
\text { Coefficients } \\
\text { Beta }\end{array}$} & \multirow[t]{2}{*}{$\mathbf{T}$} & \multirow[t]{2}{*}{ Sig. } \\
\hline & & B & Std. Error & & & \\
\hline \multirow[t]{3}{*}{1} & (Constant) & 0,297 & 0,175 & & 1,694 & 0,094 \\
\hline & Citra Merek & 0,427 & 0,092 & 0,450 & 4,669 & 0,000 \\
\hline & Kualitas Pelayanan & 0,504 & 0,100 & 0,484 & 5,021 & 0,000 \\
\hline \multirow{3}{*}{\multicolumn{7}{|c|}{$\begin{array}{ll}\mathrm{R}^{2} & : 0,827 \\
\text { F statistik }: & 231,866 \\
\end{array}$}} \\
\hline & & & & & & \\
\hline & & & & & & \\
\hline
\end{tabular}

Berdasarkan hasil analisis jalur substruktur 1 seperti yang disajikan pada tabel 1 maka persamaan strukturalnya adalah sebagai berikut:

$$
\begin{array}{ll}
\mathrm{M} & =\beta_{1} \mathrm{X}_{1}+\beta_{2} \mathrm{X}_{2}+\mathrm{e}_{1} \ldots \ldots \ldots \\
\mathrm{M} & =0,450 \mathrm{X}_{1}+0,484 \mathrm{X}_{2}+\mathrm{e}_{1}
\end{array}
$$

Nilai $\beta_{1}$ adalah sebesar 0,450 memiliki arti citra merek berpengaruh positif signifikan terhadap nilai pelanggan, dengan kata lain jika faktor citra merek meningkat maka nilai pelanggan meningkat.

Nilai $\beta_{2}$ adalah sebesar 0,484 memiliki arti kualitas pelayanan berpengaruh positif signifikan terhadap nilai pelanggan, dengan kata lain jika faktor kualitas pelayanan meningkat maka nilai pelanggan meningkat sebesar 0,484.

Tabel 2.

\begin{tabular}{|c|c|c|c|c|c|c|}
\hline \multirow[t]{2}{*}{ Model } & & \multicolumn{2}{|c|}{$\begin{array}{c}\text { Unstandardized } \\
\text { Coefficients }\end{array}$} & \multirow{2}{*}{$\begin{array}{c}\text { Standardized } \\
\text { Coefficients } \\
\text { Beta }\end{array}$} & \multirow[t]{2}{*}{$\mathbf{t}$} & \multirow[t]{2}{*}{ Sig. } \\
\hline & & B & Std. Error & & & \\
\hline \multirow[t]{4}{*}{1} & (Constant) & 0,228 & 0,180 & & 1,268 & 0,208 \\
\hline & Citra Merek & 0,322 & 0,102 & 0,341 & 3,148 & 0,002 \\
\hline & Kualitas Pelayanan & 0,359 & 0,114 & 0,346 & 3,156 & 0,002 \\
\hline & Nilai Pelanggan & 0,254 & 0,102 & 0,255 & 2,474 & 0,015 \\
\hline $\mathrm{R} 2^{2}$ & $: 0,824$ & & & & & \\
\hline F statistik & $: 149,360$ & & & & & \\
\hline Sig. F & : 0,000 & & & & & \\
\hline
\end{tabular}

Hasil Analisis Jalur Persamaan Regresi 2

Berdasarkan data yang disajikan pada Tabel 2, maka persamaan strukturalnya dapat disusun sebagai berikut:

$\mathrm{Y}={ }_{3} \mathrm{X}_{1}+\beta_{4} \mathrm{X}_{2}+\beta_{5} \mathrm{M}+\mathrm{e}_{2}$

$\mathrm{Y}=0,341 \mathrm{X}_{1}+0,346 \mathrm{X}_{2}+0,255 \mathrm{Y}_{1}+\mathrm{e}_{2}$ 
Nilai $\beta_{3}$ adalah sebesar 0,341 memiliki arti citra merek berpengaruh positif signifikan terhadap kepuasan pelanggan, dengan kata lain jika faktor citra merek meningkat maka kepuasan pelanggan meningkat.

Nilai $\beta_{4}$ adalah sebesar 0,346 memiliki arti kualitas pelayanan berpengaruh positif signifikan terhadap kepuasan pelanggan, dengan kata lain jika faktor kualitas pelayanan meningkat maka kepuasan pelanggan meningkat.

Nilai $\beta_{5}$ adalah sebesar 0,255 memiliki arti nilai pelanggan berpengaruh positif signifikan terhadap kepuasan pelanggan, dengan kata lain jika faktor nilai pelanggan meningkat maka kepuasan pelanggan meningkat.

Menguji Nilai Koefisien Determinasi $\left(\mathrm{R}^{2}\right)$ dan Standard Error (E) Berdasarkan persamaan regresi 1 dan 2 , diketahui nilai dari $\mathrm{R}_{1}{ }^{2}=0,827$ dan $\mathrm{R}_{2}^{2}=$ 0,824 maka nilai error untuk masing-masing persamaan dihitung sebagai berikut: $\mathrm{e}=\sqrt{1-R^{2}}$.

$\mathrm{e}_{1}=\sqrt{1-R 1^{2}}=\sqrt{1-0,827}=0,415$

$\mathrm{e}_{2}=\sqrt{1-R 2^{2}}=\sqrt{1-0,824}=0,419$

Berdasarkan perhitungan di atas, diketahui besarnya pengaruh $\mathrm{e}_{1}=0,415$ dan nilai dari $\mathrm{e}_{2}=0,419$. Dari nilai $\mathrm{e}_{1}$ dan $\mathrm{e}_{2}$ yang telah diketahui maka koefisien determinasi total dapat dihitung sebagai berikut:

$\mathrm{R}^{2} \mathrm{~m}=1-\left(\mathrm{Pe}_{1}\right)^{2}\left(\mathrm{Pe}_{2}\right)^{2}$.

$=1-(0,415)^{2}(0,419)^{2}$

$=1-(0,172)(0,175)$

$=1-0,030=0,97$

Koefisien determinasi total sebesar 0,97 artinya sebesar 97 persen variasi variabel kepuasan pelanggan dipengaruhi oleh variabel nilai pelanggan, citra merek dan kualitas pelayanan, sedangkan sisanya sebesar 3 persen dijelaskan oleh faktor lain yang tidak dimasukkan ke dalam model.

Hasil pengujian pada Tabel 2 diperoleh nilai koefisien signifikansi $\mathrm{F} \leq 0,05$ dengan koefisien signifikan $0,000 \leq 0,05$, sehingga $\mathrm{H}_{0}$ ditolak dan $\mathrm{H}_{1}$ diterima. Hasil tersebut menunjukkan bahwa citra merek, kualitas pelayanan dan nilai pelanggan berpengaruh secara signifikan terhadap kepuasan pelanggan. Model persamaan struktural dalam penelitian ini telah memenuhi syarat goodness of fit melalui uji F.

Hasil dari analisis diketahui pengaruh citra merek terhadap kepuasan pelanggan memiliki koefisien $\beta_{3}=0,341$ dan $p$ value sebesar 0,002 . Nilai koefisien $\beta_{3}>0$ dan $p$ value $\leq 0,05$ sehingga $\mathrm{H}_{3}$ diterima dan $\mathrm{H}_{0}$ ditolak. Itu berarti citra merek berpengaruh positif dan signifikan terhadap kepuasan pelanggan.

Hasil pada Tabel 2 diketahui pengaruh kualitas pelayanan terhadap kepuasan pelanggan memiliki koefisien $\beta_{4}=0,346$ dan $p$ value sebesar 0,002 . Nilai koefisien $\beta_{4}>0$ dan $p$ value $\leq 0,05$ sehingga $\mathrm{H}_{4}$ diterima dan $\mathrm{H}_{0}$ ditolak. Itu berarti kualitas pelayanan berpengaruh positif dan signifikan terhadap kepuasan pelanggan.

Hasil pada Tabel 2. diketahui pengaruh kepuasan pelanggan terhadap kepuasan pelanggan memiliki koefisien $\beta_{5}=0,255$ dan $p$ value sebesar 0,015 . Nilai koefisien $\beta_{5}>0$ dan $p$ value $\leq 0,05$ sehingga $\mathrm{H}_{5}$ diterima dan $\mathrm{H}_{0}$ ditolak. Itu berarti nilai pelanggan berpengaruh positif dan signifikan terhadap kepuasan pelanggan. 
Besarnya pengaruh langsung, pengaruh tidak langsung dan pengaruh total antar variabel. Perhitungan pengaruh antar variabel ditunjukkan pada tabel berikut:

Tabel 3.

Pengaruh Langsung, Pengaruh Tidak Langsung dan Pengaruh Total Citra Merek ( $\left.X_{1}\right)$, Kualitas Pelayanan $\left(X_{2}\right)$, Nilai Pelanggan $(M)$, dan Kepuasan Pelangan (Y)

\begin{tabular}{cccc}
\hline $\begin{array}{c}\text { Pengaruh } \\
\text { Variabel }\end{array}$ & $\begin{array}{c}\text { Pengaruh } \\
\text { Langsung }\end{array}$ & $\begin{array}{c}\text { Pengaruh Tidak langsung } \\
\text { Melalui Kepuasan Pelanggan }\end{array}$ & Pengaruh Total \\
\hline $\mathrm{X}_{1} \rightarrow \mathrm{M}$ & 0,450 & - & - \\
$\mathrm{X}_{2} \rightarrow \mathrm{M}$ & 0,484 & - & - \\
$\mathrm{X}_{1} \rightarrow \mathrm{Y}$ & 0,341 & 0,114 & 0,455 \\
$\mathrm{X}_{2} \rightarrow \mathrm{Y}$ & 0,346 & 0,123 & 0,469 \\
$\mathrm{M} \rightarrow \mathrm{Y}$ & 0,255 & - & - \\
\hline
\end{tabular}

Sumber: Data diolah, 2018

Data tersebut menunjukkan bahwa citra merek berpengaruh langsung terhadap kepuasan pelanggan sebesar 34,1 persen, dengan dimediasi nilai pelanggan maka didapatkan pengaruh tidak langsung sebesar 11,4 persen, dan pengaruh total sebesar 45,5 persen. Hasil tersebut menunjukkan bahwa nilai pelanggan memediasi hubungan citra merek terhadap kepuasan pelanggan secara parsial.

Tabel juga menunjukkan pengaruh langsung variabel kualitas pelayanan terhadap kepuasan pelanggan sebesar 34,6 persen serta pengaruh tidak langsung yang dimediasi nilai pelanggan memperoleh nilai beta sebesar 12,3 persen, hal tersebut menunjukkan bahwa nilai pelanggan memediasi pengaruh kualitas pelayanan terhadap kepuasan pelanggan dengan pengaruh total sebesar 46,9 persen. Hasil tersebut menunjukkan bahwa nilai pelanggan memediasi secara parsial hubungan kualitas pelayanan terhadap kepuasan pelanggan.

Untuk menguji apakah data yang digunakan normal atau tidak dapat dilakukan dengan menggunakan uji Kolmogorov Smirnov. Apabila koesifien Asymp. Sig. (2-tailed) lebih besar dari 0,05 maka data tersebut dikatakan berdistribusi normal.

Tabel 4.

Hasil Uji Normalitas Persamaan Regresi 1

\begin{tabular}{cc}
\hline & Unstandardized Residual \\
\hline $\mathrm{N}$ & 100 \\
Kolmogorov Smirnov & 1.073 \\
Asymp. Sig. (2-tailed) & 0.200 \\
\hline
\end{tabular}

Sumber: Data diolah, 2018

Berdasarkan Tabel 4. maka dapat dilihat bahwa nilai Kolmogorov Smirnov $(K-S)$ sebesar 1,073 sedangkan nilai Asymp. Sig. (2-tailed) sebesar 0,200. Hasil tersebut mengindikasikan bahwa model persamaaan regresi tersebut berdistribusi normal karena nilai Asymp. Sig. (2-tailed) sebesar 0,200 dimana lebih besar dari nilai alpha yaitu 0,05 . 
Berdasarkan Tabel 5. maka dapat dilihat bahwa nilai Kolmogorov Smirnov $(K-S)$ sebesar 1,239 sedangkan nilai Asymp. Sig. (2-tailed) sebesar 0,093. Hasil tersebut mengindikasikan bahwa model persamaaan regresi tersebut berdistribusi normal karena nilai Asymp. Sig. (2-tailed) sebesar 0,093 dimana lebih besar dari nilai alpha yaitu 0,05 . Sebagai berikut:

Tabel 5.

Hasil Uji Normalitas Persamaan Regresi 2

\begin{tabular}{cc}
\hline & Unstandardized Residual \\
\hline $\mathrm{N}$ & 100 \\
Kolmogorov Smirnov & 1.239 \\
Asymp. Sig. (2-tailed) & 0,093 \\
\hline
\end{tabular}

Sumber:Data diolah, 2018

Adanya multikolinieritas dapat dilihat dari nilai tolerance atau variance inflaction factor (VIF). Jika nilai tolerance lebih dari 10\% atau VIF kurang dari 10, maka dapat dikatakan tidak ada multikolinieritas.

Tabel 6.

Hasil Uji Multikolinieritas Persamaan Regresi 1

\begin{tabular}{lcc}
\hline Variabel & Tolerance & VIF \\
\hline Citra Merek & 0,192 & 5,202 \\
Kualitas Pelayanan & 0,192 & 5,202 \\
\hline
\end{tabular}

Sumber: Data diolah, 2018

Berdasarkan Tabel 6. dapat dilihat nilai tolerance dan VIF dari varibel citra merek dan kualitas pelayanan. Nilai tersebut menunjukkan bahwa nilai tolerance untuk setiap variabel lebih besar dari 10 persen dan nilai VIF lebih kecil dari 10 yang berarti model persamaan regresi 1 bebas dari multikolinieritas.

Tabel 7.

Hasil Uji Multikolinieritas Persamaan Regresi 2

\begin{tabular}{lcc}
\hline \multicolumn{1}{c}{ Variabel } & Tolerance & VIF \\
\hline Citra Merek & 0,157 & 6,371 \\
Kualitas Pelayanan & 0,153 & 6,554 \\
Nilai Pelanggan & 0,173 & 5,781 \\
\hline
\end{tabular}

Sumber: Data diolah, 2018

Berdasarkan Tabel 7. dapat dilihat nilai tolerance dan VIF dari varibel citra merek, kualitas pelayanan dan nilai pelanggan. Nilai tersebut menunjukkan bahwa nilai tolerance untuk setiap variabel lebih besar dari 10 persen dan nilai VIF lebih kecil dari 10 yang berarti model persamaan regresi 2 bebas dari multikolinieritas.

Peran nilai pelanggan memediasi citra merek terhadap kepuasan pelanggan dapat dihitung dengan uji sobel sebagai berikut:

$$
\mathrm{z}=\frac{\mathrm{ab}}{\sqrt{\mathrm{b}^{2} \mathrm{Sa}^{2}+\mathrm{a}^{2} \mathrm{Sb}^{2}+\mathrm{Sa}^{2} \mathrm{Sb}^{2}}}
$$

Keterangan:

$$
\begin{array}{ll}
\mathrm{a} & =0,450 \\
\mathrm{~S}_{\mathrm{a}} & =0,092 \\
\mathrm{~b} & =0,255
\end{array}
$$




$$
\begin{aligned}
\mathrm{S}_{\mathrm{b}} & =0,102 \\
\mathrm{Z} & =\frac{\mathrm{ab}}{\sqrt{\mathrm{a}^{2} \mathrm{Sb}^{2}+\mathrm{b}^{2} \mathrm{Sa}^{2}+\mathrm{Sa}^{2} \mathrm{Sb}^{2}}} \\
\mathrm{Z} & =\frac{(0,450)(0,225)}{\sqrt{(0,450)^{2}(0,102)^{2}+(0,255)^{2}(0,092)^{2}+(0,092)^{2}(0,102)^{2}}} \\
\mathrm{Z} & =\frac{0,1148}{0,0529} \\
\mathrm{Z} & =2,1901
\end{aligned}
$$

Hasil Uji Sobel yang telah dihitung menunjukkan bahwa nilai koefisien $\mathrm{z}$ adalah 2,1901 $>1,96$ dengan tingkat signifikansi $0,0285<0,05$, sehingga $\mathrm{H}_{0}$ ditolak dan $\mathrm{H}_{1}$ diterima. Hasil tersebut mengartikan bahwa nilai pelanggan sebagai variabel mediasi dinilai secara positif dan signifikan mampu memediasi pengaruh citra merek terhadap kepuasan pelanggan.

Peran nilai pelanggan memediasi kualitas pelayanan dengan kepuasan pelanggan dapat diuji dengan uji sobel sebagai berikut:

$$
\begin{array}{ll}
\mathrm{Z} & =\frac{\mathrm{ab}}{\sqrt{\mathrm{b}^{2} \mathrm{Sa}^{2}+\mathrm{a}^{2} \mathrm{Sb}^{2}+\mathrm{Sa}^{2} \mathrm{Sb}^{2}}} \\
\text { Keterangan: } & \\
\mathrm{a} & =0,484 \\
\mathrm{~S}_{\mathrm{a}} & =0,100 \\
\mathrm{~b} & =0,255 \\
\mathrm{~S} & =0,102 \\
\mathrm{Z} & =\frac{\mathrm{ab}}{\sqrt{\mathrm{a}^{2} \mathrm{Sb}^{2}+\mathrm{b}^{2} \mathrm{Sa}^{2}+\mathrm{Sa}^{2} \mathrm{Sb}^{2}}} \\
\mathrm{Z} & =\frac{(0,484)(0,255)}{\sqrt{(0,484)^{2}(0,102)^{2}+(0,255)^{2}(0,100)^{2}+(0,100)^{2}(0,102)^{2}}} \\
\mathrm{Z} & =\frac{0,1234}{0,0567} \\
\mathrm{Z} & =2,1847
\end{array}
$$

Hasil Uji Sobel yang telah dihitung menunjukkan bahwa nilai koefisien z adalah 2,1847 > 1,96 dengan tingkat signifikansi $0,0289<0,05$, sehingga $\mathrm{H}_{0}$ ditolak dan $\mathrm{H}_{1}$ diterima. Hasil tersebut mengartikan bahwa nilai pelanggan sebagai variabel mediasi dinilai secara positif dan signifikan mampu memediasi pengaruh kualitas pelayanan terhadap kepuasan pelanggan.

Pengaruh antara kualitas pelayanan terhadap kepuasan pelanggan dalam penelitian ini diperoleh nilai koefisien $\beta_{1}$ sebesar 0,450 dengan tingkat signifikansi $0,002 \leq 0,05$ sehingga $\mathrm{H}_{1}$ diterima dan $\mathrm{H}_{0}$ ditolak, yang mengindikasikan bahwa citra merek berpengaruh positif dan signifikan terhadap nilai pelanggan. Itu berarti, semakin baik citra merek PT. Agung Automall Gianyar maka akan semakin meningkat nilai pelanggan yang dirasakan oleh pelanggan PT. Agung Automall Gianyar tersebut.

Hasil penelitian ini sejalan dengan penelitian sebelumnya yang dilakukan oleh Kotler \& Armstrong (2012), Solechah \& Soliha (2015), Wardhana (2013) dan Antonio (2007) yang menunjukkan bahwa citra merek berpengaruh positif dan signifikan terhadap nilai pelanggan.

Pengaruh antara kualitas pelayanan terhadap nilai pelanggan dalam penelitian ini diperoleh nilai koefisien $\beta_{2}$ sebesar 0,484 dengan tingkat signifikansi $0,002 \leq$ 
0,05 sehingga $\mathrm{H}_{2}$ diterima dan $\mathrm{H}_{0}$ ditolak, yang mengindikasikan bahwa kualitas pelayanan berpengaruh positif dan signifikan terhadap nilai pelanggan. Itu berarti, semakin baik kualitas pelayanan yang diberikan PT. Agung Automall Gianyar maka akan semakin meningkat nilai pelanggan yang dirasakan oleh pelanggan PT. Agung Automall Gianyar tersebut.

Hasil penelitian ini sejalan dengan penelitian sebelumnya yang dilakukan oleh Andhansari et al. (2012), Kanthi et al. (2016), Razavi et al. (2012), dan Lee \& Lee (2011) yang menunjukkan bahwa kualitas pelayanan berpengaruh positif dan signifikan terhadap nilai pelanggan.

Pengaruh antara citra merek terhadap kepuasan pelanggan dalam penelitian ini diperoleh nilai koefisien $\beta_{3}$ sebesar 0,341 dengan tingkat signifikansi $0,015 \leq$ 0,05 sehingga $\mathrm{H}_{3}$ diterima dan $\mathrm{H}_{0}$ ditolak, yang mengindikasikan bahwa citra merek berpengaruh positif dan signifikan terhadap kepuasan pelanggan. Itu berarti, semakin baik citra merek PT. Agung Automall Gianyar maka akan semakin meningkatkan kepuasan pelanggan yang dirasakan oleh pelanggan PT. Agung Automall Gianyar.

Hasil penelitian ini sejalan dengan penelitian sebelumnya yang dilakukan oleh Herliza \& Saputri (2016), Kunaifi (2015), Pusparani \& Rastini (2014) menunjukkan bahwa citra merek berpengaruh positif dan signifikan terhadap kepuasan pelanggan.

Pengaruh antara kualitas pelayanan terhadap kepuasan pelanggan dalam penelitian ini diperoleh nilai koefisien $\beta_{4}$ sebesar 0,346 dengan tingkat signifikansi $0,000 \leq 0,05$ sehingga $\mathrm{H}_{4}$ diterima dan $\mathrm{H}_{0}$ ditolak, yang mengindikasikan bahwa kualitas pelayanan berpengaruh positif dan signifikan terhadap kepuasan pelanggan. Itu berarti, semakin baik kualitas pelayanan diberikan oleh PT. Agung Automall Gianyar maka akan semakin mendorong terciptanya kepuasan pelanggan yang dirasakan pelanggan PT. Agung Automall Gianyar.

Hasil penelitian ini sejalan dengan penelitian sebelumnya yang dilakukan oleh Hidayat (2009), Lee \& Lee (2011), dan Patawayati et al. (2013) menunjukkan bahwa kualitas pelayanan berpengaruh positif dan signifikan terhadap kepuasan pelanggan.

Pengaruh antara nilai pelanggan terhadap kepuasan pelanggan dalam penelitian ini diperoleh nilai koefisien $\beta_{5}$ sebesar 0,255 dengan tingkat signifikansi $0,000 \leq 0,05$ sehingga $\mathrm{H}_{5}$ diterima dan $\mathrm{H}_{0}$ ditolak, yang mengindikasikan bahwa nilai pelanggan berpengaruh positif dan signifikan terhadap kepuasan pelanggan. Itu berarti, semakin tinggi nilai pelanggan yang dirasakan oleh pelanggan setelah menggunakan layanan jasa service PT. Agung Automall Gianyar maka akan semakin mendorong meningkatnya intensitas kepuasan pelanggan PT. Agung Automall Gainyar.

Hasil penelitian ini sejalan dengan penelitian sebelumnya yang dilakukan oleh Palilati (2007), Iskandar \& Dendy (2013), dan Febrianto (2010) menunjukkan bahwa nilai pelanggan berpengaruh positif dan signifikan terhadap kepuasan pelanggan. Hasil uji pengaruh langsung variabel citra merek terhadap kepuasan pelanggan semula bernilai 0,341 , kemudian setelah adanya niali pelanggan sebagai variabel mediasi, nilai pada pengaruh citra merek terhadap kepuasan pelanggan meningkat menjadi sebesar 0,457. Hasil tersebut menunjukkan bahwa nilai 
pelanggan memediasi hubungan citra merek terhadap kepuasan pelanggan secara parsial. Hasil uji sobel menunjukkan bahwa nilai pelanggan secara positif dan signifikan memediasi pengaruh citra merek terhadap kepuasan pelanggan. Nilai uji sobel pengaruh citra merek terhadap kepuasan pelanggan melalui nilai pelanggan adalah sebesar $Z=2,1901>1,96$ dan tingkat signifikansi $0,0285<0,05$. Nilai uji sobel di atas menunjukkan bahwa nilai pelanggan mampu memediasi pengaruh citra merek terhadap kepuasan pelanggan secara positif dan signifikan.

Nilai pelanggan memediasi pengaruh citra merek untuk menimbulkan kepuasan pelanggan. Terdapat banyak hal positif yang diterima oleh perusahaan jika perusahaan salah satunya adalah terciptanya kepuasan pelanggan yang positif. Pelanggan yang merasa puas berpotensi untuk merekomendasikan dan mendorong rekan-rekannya untuk menggunakan jasa service PT. Agung Automall Gianyar.

Hasil penelitian ini sejalan dengan penelitian sebelumnya yang dilakukan oleh Pramudyo (2012), Antonio (2007), dan Bestari \& Nurdasila (2017) dalam penelitiannya menunjukkan adanya pengaruh citra merek terhadap kepuasan pelanggan secara tidak langsung, dimana nilai pelanggan menjadi variabel mediasi. Hasil uji pengaruh langsung kualitas pelayanan terhadap kepuasan pelanggan semula bernilai 0,346 , kemudian setelah adanya nilai pelanggan sebagai variabel mediasi, nilai pada pengaruh citra merek terhadap WOM meningkat menjadi sebesar 0,465. Hasil tersebut menunjukkan bahwa nilai pelanggan memediasi secara parsial pengaruh kualitas pelayanan terhadap kepuasan pelanggan secara parsial.

Hasil uji sobel menunjukkan bahwa nilai pelanggan secara positif dan signifikan memediasi pengaruh kualitas pelayanan terhadap kepuasan pelanggan. Hasil uji sobel menunjukkan bahwa nilai pelanggan secara positif dan signifikan memediasi pengaruh kualitas pelayanan terhadap kepuasan pelanggan. Nilai uji sobel untuk pengaruh kualitas pelayanan terhadap kepuasan pelanggan melalui nilai pelanggan sebesar hasil $\mathrm{Z}=2,1847>1,96$ dan tingkat signifikansi $0,0289<$ 0,05 . Nilai uji sobel di atas menunjukkan bahwa nilai pelanggan positif dan signifikan memediasi pengaruh kualitas pelayanan terhadap kepuasan pelanggan.

Nilai pelanggan memediasi pengaruh kualitas pelayanan untuk menimbulkan kepuasan pelanggan. Persepsi pelanggan terhadap kualitas pelayanan yang diberikan sesuai dengan manfaat yang dirasakan pelanggan akan menimbukan kepuasan pada pelanggan. Terdapat banyak hal positif yang diterima oleh perusahaan jika perusahaan salah satunya adalah terciptanya kepuasan pelanggan yang positif. Pelanggan yang merasa puas berpotensi untuk merekomendasikan dan mendorong rekan-rekannya untuk menggunakan layanan jasa service di PT. Agung Automall Gainyar.

Hasil penelitian ini sejalan dengan penelitian sebelumnya yang dilakukan oleh Palilati (2007), Aryani \& Rosinta (2010), dan (Woro \& Naili, 2013) dalam penelitiannya menunjukkan adanya pengaruh kualitas pelayanan terhadap kepuasan pelanggan secara tidak langsung, dimana nilai pelanggan menjadi variabel mediasi.

\section{SIMPULAN DAN SARAN}


Citra merek berpengaruh positif dan signifikan terhadap nilai pelanggan. Hasil ini berarti bahwa semakin baik citra merek PT. Agung Automall Gianyar maka akan semakin meningkat pula nilai pelanggan.

Kualitas pelayanan berpengaruh positif dan signifikan terhadap nilai pelanggan. Hasil ini berarti bahwa apabila semakin baik kualitas pelayanan yang diberikan oleh PT. Agung Automall Gianyar maka akan semakin meningkat nilai pelanggan.

Citra merek berpengaruh positif dan signifikan terhadap kepuasan pelanggan. Hasil ini berarti bahwa semakin baik citra merek PT. Agung Automall Gianyar maka akan meningkatkan intensitas kepuasan pelanggan yang positif.

Kualitas pelayanan berpengaruh positif dan signifikan terhadap kepuasan pelanggan. Hasil ini berarti bahwa semakin baik kualitas pelayanan yang di tawarkan oleh PT. Agung Automall Gianyar maka akan meningkatkan intensitas kepuasan pelangganyang positif dari pelanggan.

Nilai pelanggan berpengaruh positif dan signifikan terhadap kepuasan pelanggan. Hasil ini berarti bahwa semakin baik nilai pelanggan yang dirasakan pelanggan, maka akan meningkatkan intensitas kepuasan pelanggan positif terhadap layanan jasa service PT. Agung Automall Gianyar.

Peran nilai pelanggan memediasi secara positif dan signifikan hubungan citra merek terhadap kepuasan pelanggan. Hasil analisis yang diperoleh dari kedua teknik analisis menunjukkan bahwa secara positif dan signifikan nilai pelanggan mampu memediasi hubungan hubungan citra merek terhadap kepuasan pelanggan PT. Agung Automall Gianyar.

Peran nilai pelanggan memediasi secara positif dan signifikan hubungan kualitas pelayanan terhadap kepuasan pelanggan. Hasil analisis yang diperoleh dari kedua teknik analisis menunjukkan bahwa secara positif dan signifikan nilai pelanggan mampu memediasi hubungan antara kualitas pelayanan terhadap kepuasan pelanggan PT. Agung Automall Gianyar.

Bagi peneliti selanjutnya diharapkan dapat memperluas cakupan wilayah penelitian selain di wilayah Kota Gianyar dan melakukan penelitian ulang dalam titik waktu yang ditentukan.

Saran yang dapat diberikan berdasarkan simpulan yang dipaparkan kepada perusahaan dan penelitian selanjutnya, sebagai berikut:

PT. Agung Automall Gianyar diharapkan mampu meningkatkan kualitas pelayanannya agar selalu diingat oleh pelanggan jika ingin melakukan service mobil dengan cara meningkatkan kualitas pelayanan.

Karyawan PT. Agung Automall Gianyar diharapkan selalu tanggap dalam menghadapi keluh kesah dan masalah para pelanggannya agar pelanggan senantiasa merasa puas dengan PT. Agung Automall Gianyar dengan cara melakukan pelatihan terhadap karyawan baru dan juga karyawan lama.

PT. Agung Automall Gainyar diharapkan lebih meningkatkan nilai kualitas pelayanan service-nya agar dapat memuaskan pelanggannya dengan cara selalu mengedepankan kualitas pelayanan sebagai faktor utama kepuasan pelanggan. PT. Agung Automall Gianyar diharapkan mampu memberikan pelayanan yang maksimal sehingga membuat pelanggan berminat untuk berkunjung kembali dengan cara menambah kursi pijat yang ada. 
Bagi peneliti selanjutnya diharapkan dapat memperluas cakupan wilayah penelitian selain di wilayah Kota Gianyar dan melakukan penelitian ulang dalam titik waktu yang ditentukan. Jumlah variabel yang diteliti dalam penelitian ini hanya terbatas pada variabel citra merek, kualitas pelayanan, nilai pelanggan dan kepuasan pelanggan untuk penelitian selanjutnya dapat menambahkan variabel berupa variabel promosi dan variabel harga.

Beberapa keterbatasan penelitian yang dapat ditarik dari penelitian ini adalah sebagai berikut. Ruang lingkup penelitian yang hanya dilakukan di Kota Gianyar, sehingga hasil dari penelitian ini tidak dapat digeneralisasi untuk konsumen yang berada diluar wilayah Kota Gianyar. Penelitian ini hanya dilakukan dalam titik waktu tertentu (cross section) sedangkan lingkungan setiap saat dapat berubah, sehingga penelitian ini penting untuk dilakukan kembali di masa mendatang. Jumlah variabel yang diteliti dalam penelitian ini hanya terbatas pada variabel citra merek, kualitas pelayanan, nilai pelanggan dan kepuasan pelanggan.

\section{REFERENSI}

Andhansari, P., Lubis, N., \& Wijayanto, A. (2012). Pengaruh Kualitas Pelayanan dan Nilai Pelanggan terhadap Kepuasan Pelanggan (Studi Kasus pada Penumpang Bus PO. Haryanto Kudus). Jurnal Manajemen, 10(9), 3-8.

Antonio, M. S. (2007). The Super Leader Super Manager. Jakarta: Tazkia Multimedia \& Prolm Centre.

Ariffin, A. A. M., \& Maghzi, A. (2012). A preliminary study on customer expectations ofhotel hospitality: influences of personal and hotel factors. International Journal of Hospitality Management, 31(1), 191-198. https://doi.org/10.1016/j.ijhm.2011.04.012

Aryadhe, P., \& Rastini, N. M. (2016). Kualitas Pelayanan, Kualitas Produk Dan Citra Merek Terhadap Niat Beli Ulang di PT. Agung Toyota Denpasar. EJurnal Manajemen Unud, 5(9), 5695-5721.

Aryani, D., \& Rosinta, F. (2010). Pengaruh Kualitas Layanan terhadap Kepuasan Pelanggan dalam Membentuk Loyalitas Pelanggan. Jurnal Ilmu Administrasi Dan Organisasi, 17(2), 114-126.

Bestari, I., \& Nurdasila. (2017). Pengaruh citra merek dan kewajaran harga terhadap loyalitas merek dengan kepuasan pelanggan sebagai pemediasi pada pengguna produk apple di kota banda aceh. Jurnal Ilmiah Mahasiswa Ekonomi Manajemen, 2(3), 86-94.

Bowen, J. T., \& McCain, S.-L. C. (2015). Transitioning loyalty programs: a commentary on "the relationship between customer loyalty and customer satisfaction." International Journal of Contemporary Hospitality Management, 27(3), 415-430. 
Dewi, L. N. (2013). Analisis Pengaruh Kualitas Produk, Citra Merek, Kepercayaan, dan Kepuasan terhadap Loyalitas Pengguna Produk Advan di Kota Semarang. Jurnal Dinus, 1-17. Retrieved from http://dinus.ac.id/

Febrianto, D. (2010). Analisa Pengaruh Nilai Pelanggan terhadap Kepuasan Pelanggan dalam Upaya Minat Beli Ulang Produk Handphone Merek Nokia di Surabaya. Universitas Pembangunan Nasional "Veteran.

Gaspersz, V. (2004). Production Planning and Inventory Control. Jakarta: PT. Gramedia Pustaka Umum.

Gilbert, G. R., Veloutsou, C., Goode, M. M. H., \& Moutinho, L. (2004). Measuring Customer Satisfaction In The Fast Food Industry : A cross-national approach. Journal of Services Marketing, 18(5), 371-383.

Hardiansyah. (2011). Kualitas Pelayanan Publik. Yogyakarta: Gava Media.

Herliza, R., \& Saputri, M. E. (2016). Pengaruh Brand Image terhadap Kepuasan Pelanggan Studi pada Zara di Mall PVJ Bandung (The Influencer of Brand Image to Customer Satisfaction A Case Study). E-Proceeding of Management, 3(2), 1949-1955.

Hidayat, R. (2009). Pengaruh Kualitas Layanan, Kualitas Produk dan Nilai Nasabah Terhadap Kepuasan dan Loyalitas Nasabah Bank Mandiri. Jurnal Manajemen Dan Kewirausahaan, 11(1), 59-72. https://doi.org/10.9744/jmk.11.1.pp.\%2059-72

Iskandar, V., \& Dendy, A. K. (2013). Analisa Pengaruh Nilai Pelanggan Terhadap Kepuasan Pelanggan Pada Alex' s Salon Darmo Park. Jurnal Hospitality Dan Manajemen Jasa, 1(2), 204-214.

Kanthi, Y. A., Suharyono, \& Kumadji, S. (2016). Pengaruh Kualitas Layanan terhadap Nilai Pelanggan, Kepuasan Pelanggan dan Loyalitas Pelanggan (Studi pada Klinik dr. Sumakto, Sp. A(K) di Malang). Jurnal Fakultas Ilmu Administrasi Universitas Brawijaya, 10(1), 34-45. https://doi.org/10.9876/10.9876/VOL1ISSN1978-743X

Keyser, A. De, \& Lariviere, B. (2014). How technical and functional service quality drive consumer happiness: Moderating influences of channel usage. Journal of Service Management, 25(1), 30-48. https://doi.org/10.1108/JOSM-042013-0109

Kotler, P., \& Armstrong, G. (2012). Principles of Marketing. New Jersey: Prentice Hall. 
Kumalasari, N. (2018). Analisis Pengaruh Citra Merek, Kualitas Produk, dan Kualitas Pelayanan terhadap Kepuasan dan Loyalitas Konsumen Tempe 5.17 Salatiga. Jurnal Publikasi Universitas Islam Indonesia. Retrieved from https://dspace.uii.ac.id/handle/123456789/7516

Kunaifi, D. A. (2015). Pengaruh Kualitas Produk dan Citra Merek terhadap Kepuasan Konsumen pada Produk Eiger di Surakarta. Universitas Muhammadiyah Surakarta.

Lai, F., Griffin, M., \& Babin, B. J. (2009). How quality, value, image, and satisfaction create loyalty at a Chinese telecom. Journal of Business Research, 62(10), 980-986.

Lee, H. S. (2013). Major Moderators Influencing the Relationships of Service Quality, Customer Satisfaction and Customer Loyalty. Asian Social Science, 9(2), 1-11. https://doi.org/10.5539/ass.v9n2p1

Lee, W. I., \& Lee, C. L. (2011). An Innovative Information and Relationship Between Service Quality, Customer Value, Customer Satisfaction and Purchase Intention. International Journal of Innovative Computing, Information and Control, 7(7A), 35713581.

Palilati, A. (2007). Pengaruh Nilai Pelanggan, Kepuasan Terhadap Loyalitas Nasabah Tabungan Perbankan Di Sulawesi Selatan. Jurnal Manajemen Dan Kewirausahaan, 9(1), 73-81.

Patawayati, Zain, D., Setiawan, M., \& Rahayu, M. (2013). Patient Satisfaction, Trust and Commitment: Mediator of Service Quality and Its Impact on Loyalty (An Empirical Study in Southeast Sulawesi Public Hospitals). Journal of Business and Management, 7(6), 1-14.

Permana, A. R. (2016). Pengaruh Citra Merek Dan Kualitas Pelayanan Terhadap Kepuasan Konsumen Pada Starbucks Bandung Indah Plaza (Survey Pada Konsumen Starbucks Bandung Indah Plaza). Universitas Pasundan.

Pramana, I. G. Y., \& Rastini, N. M. (2016). Pengaruh Kualitas Pelayanan Terhadap Kepercayaan Nasabah Dan Loyalitas Nasabah Bank Mandiri Cabang Veteran Denpasar Bali. E-Jurnal Manajemen Unud, 5(1), 706-733.

Pramudyo, A. (2012). Pengaruh Citra Merek Terhadap Loyalitas Melalui Kepuasan Sebagai Intervening (Studi Pada Mahasiswa Perguruan Tinggi Swasta di Yogyakarta). JBMA, I(1), 1-16.

Pusparani, Y. A. P., \& Rastini, N. M. (2014). Pengaruh Kualitas Produk dan Brand Image Terhadap Kepuasan Konsumen dan Loyalitas Pelanggan Kamera Canon Digital Single Lens Reflex (DSLR) di Kota Denpasar. E-Jurnal Manajemen. https://doi.org/10.1016/j.cub.2015.10.018 
Raza, S. A., Jawaid, S. T., \& Hassan, A. (2015). Internet banking and customer satisfaction in Pakistan. Qualitative Research in Financial Markets, 7(1), 2436. https://doi.org/10.1108/QRFM-09-2013-0027

Razavi, S. M., Safari, H., Shafie, H., \& Khoram, K. (2012). Relationships among Service Quality, Customer Satisfaction and Customer Perceived Value: Evidence from Iran's Software Industry. Journal of Management and Strategy, 3(3), 28-37. https://doi.org/10.5430/jms.v3n3p28

Siswanto, S., \& Widjaja, D. (2017). Pengaruh Kualitas Layanan terhadap Kepuasan Konsumen di PT. Daya Daihatsu Puri Kembangan. Jurnal Ilmiah Manajemen Bisnis, 17(2), 125-134.

Solechah, \& Soliha, E. (2015). Pengaruh Citra dan Kepercayaan terhadap Nilai Pelanggan dan Dampaknya pada Kepuasan serta Loyalitas Nasabah. 4th Economics \& Business Research Festiva, 401-410.

Sondakh, C. (2014). Kualitas Layanan, Citra Merek Dan Pengaruhnya Terhadap Kepuasan Nasabah Dan Loyalitas Nasabah Tabungan (Studi Pada Nasabah Taplus BNI Cabang Manado). Jurnal Riset Bisnis Dan Manajemen, 3(1), 1932.

Tjiptono, F. (2016). Strategi Pemasaran (Ketiga). Yogyakarta: CV. Andi Offset.

Wardhana, A. (2013). Pengaruh Kualitas Pelayanan Dan Citra Merek Bengkel Resmi Terhadap Nilai Pelanggan Serta Implikasinya Pada Kepuasan Pelanggan (Suatu Suvey Pada Pelanggan Bengkel Resmi Kendaraan MPV Di Bawah 2500 CC Di Kota Bandung). Jurnal Kebangsaan, 2(3).

Woro, M., \& Naili, F. (2013). Pengaruh Nilai Pelanggan dan Kualitas Layanan Terhadap Loyalitas Pelanggan, Melalui Kepuasan Pelanggan Pada Pelanggan Bus Efisiensi. Jurnal Administrasi Bisnis, 2(1), 64-75.

Yang, Z., \& Peterson, R. T. (2004). Customer Perceived Value, Satisfaction, and Loyalty: The Role of Switching Costs. Journal of Psychology and Marketing, 21(10), 799-822. https://doi.org/10.1002/mar.20030 